\title{
A teljesítménystratégiák és a hangulati állapotok összefüggéseinek elemzése két egyetemi kosárlabdacsapatban
}

\section{Performance Strategies and State of Mood in Two University Basketball Teams}

\author{
Soós István', Martinez, Jose Carlos Flores², Hamar Pál3 , Kalmár \\ Zsuzsanna ${ }^{3}$, Whyte, lan', Szabó Attila ${ }^{4}$
}

\author{
1 University of Sunderland, Department of Sport and Exercise Sciences, Sunderland, Egyesült Királyság \\ 2 University of Almeria, Department of Psychology, Almeria, Spanyolország \\ 3 Testnevelési Egyetem, Tanárképző Intézet, Budapest \\ 4 Testnevelési Egyetem, Torna, RG, Tánc és Aerobik Tanszék, Budapest \\ 5 Eötvös Loránd Tudományegyetem, Egészségfejlesztési és Sporttudományi Intézet, Budapest
}

\begin{abstract}
Absztrakt: A teljesítménystratégiák és a hangulati állapotok fontos szerepet játszanak a sportsikerek elérésében. Tanulmányunk célja, hogy két férfi kosárlabdacsapatban feltárjuk a kapcsolódási pontokat e két mentális tényezó között. A Brit Egyetemi Bajnokság (BUCS) tizennégy hallgatója (átlagéletkoruk 22,9 év) töltötte ki a Teljesítménystratégiák Tesztet és a Brunel Hangulati Skálát, először edzés-, majd mérkőzésszituáció előtt. Közülük hét játékos első osztályú, hét pedig másodosztályú csapatban szerepel. Eredményeink arra utalnak, hogy az első osztályban játszó csapat játékosainak technikai és taktikai képességei jobban automatizáltak, mint a másodosztályban játszó csapat játékosaié. Az automatizmus csökkenésével a relaxációs szint is csökkent, viszont a feszültségi szint megemelkedett. További megállapításunk, hogy a csapatok a mérkózések során nem használják ki kellóképpen a belső beszédben rejlő lehetőségeket, ráadásul a játékosokban az életerő is csökken. Ez a jelenség részben megmagyarázza mindkét csapat sikertelenségét, melyek közül a másodosztályú csapat a kieső helyre került. Kimutatható még, hogy a beteljesületlen célkitúzések milyen lelki terhet rónak a csapatok játékosaira, ami a szakembereket megoldásra kell, hogy ösztönözze.
\end{abstract}

Kulcsszavak: teljesítménystratégiák, hangulati állapotok, kosárlabda csapatok

Abstract: Performance strategies and mood states play an important role in the achievement of success in sports. The aim of our study is to reveal the relationships between these two mental factors in two male basketball teams. Fourteen students (mean age 22.9) of the BUCS (British University and College Sport) leagues completed the Test of Performance Strategies (TOPS) and the Brunel Mood Scale (BRUMS) twice: first time prior to training; second time prior to a match. Of these players, seven played in division one and the other seven in division two. Our results uncovered that automaticity was higher in division one players compared with division two players. This seems to be due to better technical and tactical skills shown by division one players. Along with the decrease of automaticity in division 2 players, relaxation dropped as well, while tension increased. Furthermore, vigour decreased and less self-talk was used by players during the match situation as opposed to training. This phenomenon can partly explain the dysfunctional performance of players, especially as division two teams slipped towards the relegation zone. Failure to fulfil goals, puts players under unhealthy mental pressure, therefore a team of experts, who work with the players, are urged to find solutions to fix this situation. 


\section{Bevezetés}

A teljesítménystratégiák és a hangulati állapotok minden korosztályban és tudásszinten fontos szerepet játszanak a sportsikerek elérésében. Ennek kiemelkedő a jelentősége az egyetemi sportolóktól kezdve (Dachen, 2012) egészen az olimpikonokig bezárólag (Taylor, Gould és Rolo, 2008).

A kiváló sportteljesítmény tervszerủ cselekvéskoncepció végrehajtása nyomán valósul meg. A tervszerű cselekvések egymásra épülése, más néven stratégia, meghatározza egyrészt az edzések sajátosan felépített sorozatát, másrészt a mozgásprogramok, „akciók”, vagyis a specifikus viselkedési stratégiák versenyeken történő megvalósítását is. A stratégia hátterében komplex szabályozó mechanizmusok állnak. Ezek alapját nemcsak kondicionális, koordinációs, sportág-specifikus technikai és taktikai elemek alkalmazása, hanem különböző pszichológiai készségek és képességek összetevői is alkotják (Kalmár, 2014).

A sporttevékenység folyamán meghatározott célok eléréséhez egy cselekvésprogram - más szóval algoritmus - kerül kialakításra. Ennek célja kétoldalú. Egyfelől a sportoló szorongástól mentesen, vagyis nyugodtan és összpontosítva hajtsa végre a versenyfeladatát. Ehhez bizonyos relaxációs cselekvésprogramot alkalmaz, olyat, mint például a mélylégzés és a verseny előtt vagy a verseny szüneteiben történő izomellazítás. Mindez elősegíti azt, hogy a sportoló a feladatra koncentrálás során még hatékonyabban legyen képes aktiválni energiatartalékait. A hatékony relaxációs technikák elsajátítása mellett tehát a másik fó stratégiai feladat az energianövelő technikák elsajátítása. Ezen stratégiák elsajátítása az oktatás, az edzés és a versenyzés hármas egységeként valósulhat meg.

Az általános aktivitás, a nyugalom vagy izgalom bizonyos sportágaknál - mint például a labdajátékok vagy a küzdősportok - jól láthatóak. Az aktivációs szint szorosan összefügg az érzelmekkel és annak stabilabb összetevőjével, a hangulattal. A pozitív hangulat által vezérelt figyelemkoncentráció, a sikeres teljesítés érdekében történő feladatra összpontosítás, az érzelmi motiváció, a kreatív gondolkodás, valamint az ehhez kapcsolódó rugalmas tervezés nagyban elősegíti a teljesítménynövelést (Bandura, 1986; Solovey és Birnbaum, 1989).

A célkitüzés felállítása nemcsak a versenyeredmény meghatározását foglalja magában, hanem az eredményes szerepléshez vezető utat, a motivációs bázis megteremtésétől kezdődően, a figyelem-koncentráció kialakításán át, egészen annak fenntartásáig. Ez a folyamat egészen a cél eléréséig tart (Bull, 1993). Az optimális motiváció és figyelem-koncentráció eléréséhez a szervezet megfelelő éberségi, aktivációs állapotba kerül, amit ,arousalnak” (a szervezet idegi-hormonális izgalmi szintje) is nevezünk. Ez jelentősen meghatározza, hogy a sportoló mennyire képes jól teljesíteni (Gyömbér és Kovács, 2012).

A fenti képességek és készségek mérésére Thomas, Murphy és Hardy (1999) kifejlesztették a Teljesítménystratégia Tesztet, melyet - több jelentős kutató mellett - Williams, Hardy és Mutrie (2008) is alkalmasnak talált arra, hogy segítségével a szakemberek meghatározzák a teljesítménynöveléssel összefüggő pszichológiai képességek és készségek szintjét.

A Teljesítménystratégia Teszt (angolul TOPS - Test of Performance Strategies) 64 itemből álló, önértékelésen alapuló kérdőív (Thomas, Murhpy és Hardy, 1999), amely azokat a pszichológiai képességeket és stratégiákat méri, amelyeket a sportolók használnak az edzéseken és a versenyeken. Ez a kérdőív két fó részből áll, az egyik része az edzések, a másik pedig a versenyek tesztelésére szolgál. Mindkét része egyenként nyolc-nyolc alskálát foglal magában. A nyolc alskála a következő részekből tevődik össze: (1) belső beszéd (a pozitív belső dialógus fenntartására szolgál); (2) érzelmi kontroll (az érzelmek kontrolálása, szabályozása terhelés alatt); (3) automatizmus (a versenyzés vagy edzés minimális akaratlagos szabályozással történik, vagyis minden automatikusan zajlik); (4) célkitűzés (személyre szabott, specifikus célok felállítása); (5) imagináció (a sportverseny vizualizálása, vagyis az agyban/ elmében történő képi megjelenítése); (6) aktiváció (az optimális szintu” „arousal” fenntartása, az idegi-hormonális rendszer izgalmi szintje, a szervezet éberségi, aktivációs állapota, ami azt jelzi, mennyire vagyunk éberek, mennyire tudunk jól tejesíteni - Gyömbér és Kovács, 2012); (7) relaxáció (terhelés alatt is higgadtan történik a cselekvések végrehajtása mind az edzéseken, mind pedig versenykörülmények között); (8a) negatív gondolkodás (sikertelenséget felidéző gondolatok). Az edzésre vonatkozó alskálák egy kivételével megegyeznek a versenyre vonatkozó alskálákkal, ugyanis a kérdőívben a negatív gondolkodás csak a versenyzésre vonatkozó részben szerepel. E helyett a szerzők a (8b) figyelmi 
kontroll (a figyelem hatékony irányítása a feladatra) alskálát adták hozzá az edzésre vonatkozó részhez. A kutatások alapján elmondható, hogy a TOPS-ot számos alkalommal sikerrel alkalmazták a kutatók, hogy az egyes sportágaknál felmérjék és értékeljék a sportolók által használt pszichológiai képességeket és készségeket (Katsikas és mtsai, 2009).

A felhasználásra kerülő másik adatfelvételi eszköz a BRUNEL Hangulati Skála (angolul BRUMS - Brunel Mood Scale). Ez egy 32 itemből álló kérdőív, amely nyolc alskálát foglal magában. Ebből három a pozitív hangulati állapotokat, öt pedig a negatív hangulati állapotokat hivatott felmérni. A pozitív alskálák a következők: életerő (aktív, éber, energikus, élénk), nyugodtság/higgadtság (lehiggadt, nyugodt, ellazult, pihent), boldogság (jókedvű, kiegyensúlyozott, boldog, elégedett). A negatív alskálák a következők: harag (mérges, felbosszantott, rossz hangulatú, keserü), feszültség (nyugtalan, ideges, riadt, zaklatott), lehangoltság/ depresszió (levert, csüggedt, siralmas, boldogtalan), kimerültség (kimerült, álmos, fáradt, nyúzott), zavartság/összezavarodottság (zavarban levő, bizonytalan, vegyes/összevissza, zavaros).

Boldizsár és munkatársai (2016) kutatásuk során megvizsgálták a BRUMS faktorok belső konzisztenciááát, $s$ az alskálákat megbízhatónak találták (a Cronbach alpha értékek 0,70 és 0,81 közé estek, kivéve a lehangoltság/depresszió faktort, amely 0,67 értéket mutatott, ami viszont közel áll az általánosan elfogadott 0,7-es értékhez - Tavakol és Dennick leírása alapján, 2011).

Ezen tanulmány célja, feltárni a kapcsolódási pontokat a teljesítménystratégiák és a hangulati állapotok között egy első és egy másodosztályú, Brit Egyetemi Bajnokságban (BUCS - British University and College Sport) szereplő kosárlabdacsapatban.

\section{Módszerek}

A vizsgálatban önkéntesen tizennégy férfi egyetemi hallgató (átlagéletkoruk 22,9 év) vett részt. Mindannyian Észak-kelet Angliában a brit egyetemi kosárlabda bajnokság játékosai, közülük heten az első osztályban, heten pedig a másodosztályban játszottak. A játékosok edzés-, majd mérkőzésszituáció előtt töltötték ki a Teljesítménystratégia Tesztet és a Brunel Hangulati Skálát. E tanulmány második szerzője kezdetben a másodosztályú kosárlabdacsapat irányító játékosa volt, majd kiváló teljesítménye elismeréseképpen, pár hét elteltével, átkerült az első osztályú csapathoz. Az adatfelvétel körülményei ideálisak és hitelesek voltak, hiszen egy etnográfiai kutatáshoz hasonlóan - „testközelből" történtek.

A kapott adatok leíró statisztikával, Pearson korrelációval, majd kétmintás és egymintás T-próbával kerültek feldolgozásra, IBM SPSS (v23) software csomag felhasználásával.

\section{Eredmények}

Az összes válaszadó játékosnak az edzéseken magasabb szintű volt az „életereje” ( $\mathrm{p}=, 020)$, emellett több belső beszédet is használt $(\mathrm{p}=033)$, mint a mérkőzéseken. A többi teljesítménystratégia és hangulati kategóriában nem találtunk szignifikáns különbséget a vizsgált mintában (lásd 1. ábra).

Az első osztályú csapat játékosainak magasabb volt az automatizmus szintje, mint a másodosztályú csapat tagjaié $(\mathrm{p}=, 004)$. A többi teljesítménystratégia és hangulati kategóriában nem volt szignifikáns különbség az első és a másodosztályú játékosok között (lásd 2. ábra).

Az edzések és a mérkőzések teljesítménystratégiáinak és hangulati állapotainak kapcsolatát összevetve a következő összefüggések figyelhetők meg: az edzéseken szignifikáns pozitív korreláció mutatható ki a figyelemszabályozás és az érzelmi szabályozás $(\mathrm{r}=, 57, \mathrm{p}<, 05)$, valamint a célkitűzés és a feszültségi szint között $(\mathrm{r}=, 56, \mathrm{p}<, 05)$. A mérkőzéseken az automatizmus pozitívan függ össze a relaxációs $(\mathrm{r}=, 61, \mathrm{p}<, 05)$, de negatívan a feszültségi szinttel $(\mathrm{r}=-, 79, \mathrm{p}<, 01)$. Az aktivációs szint is negatívan korrelál a negatív gondolatokkal $(\mathrm{r}=-, 58, \mathrm{p}<, 05)$, illetve a depressziós szinttel $(\mathrm{r}=-, 54, \mathrm{p}<, 05)$.

\section{Megbeszélés}

Vizsgálati eredményeink arra utalnak, hogy miként ezt Taylor és munkatársai (2008) korábban már leírták - az első osztályban játszó csapat játékosainak technikai és taktikai képességei jobban automatizáltak, mint a másodosztályban játszó csapat játékosaié. Az automatizmus csökkenésével a relaxációs szint is csökken, viszont a feszültségi szint megemelkedik. Megállapítható még, hogy a csapatok a mérkőzéseken nem használják ki kellőképpen a belső beszédben rejlő lehetőségeket, ráadásul a játékosokban az életerő is csökken. Ez a jelenség részben megmagyarázza mindkét csapat sikertelenségét. Magyarázatul szolgál arra, hogy miért állnak 
ezek a csapatok a saját ligájukban a táblázat alján (a másodosztályú csapat), illetve a kieső zóna közelében (az első osztályú csapat).

A vizsgálat gyengéje (korlátja), hogy a minta elemszáma túlságosan alacsony ahhoz, hogy az adatokból messzemenő következtetéseket lehessen levonni. Ennek ellenére érdekes eredménynek tartjuk, hogy az aktiváció és az automatizmus erősen kapcsolódik a pozitív hangulati állapotokhoz. Eredményeink alapján az is kimutatható, hogy erős pozitív kapcsolódás jelentkezik az érzelmek kontrollálásának képessége és a figyelemkoncentrációs képesség között. Ezen képességek magasabb szintje magyarázat lehet arra is, hogy a stabil érzelmü/hangulatú sportolók miért képesek jobban koncentrálni a kritikus helyzetekben.

Végezetül, a vizsgált kosárlabdacsapatok esetében az is jól látható, hogy a célkitűzések meghiúsulása jelentős belső feszültséget generál a játékosokban, vagyis a játékosok sikertelensége, végső soron a beteljesületlen célkitűzések, milyen lelki terhet rónak a csapatok játékosaira. Ezek az eredmények (is) megoldáskeresésre kell, hogy ösztönözzék a szakembereket.

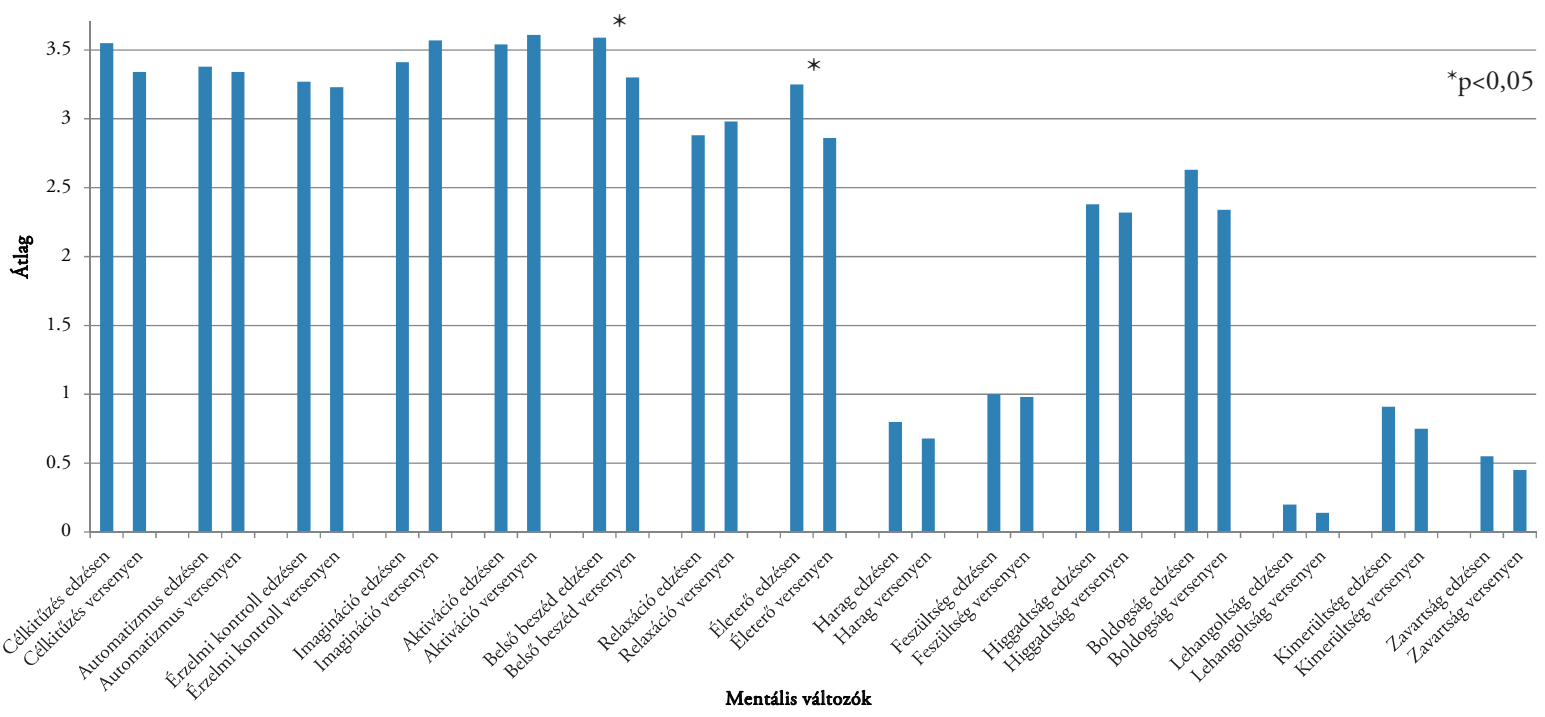

1. ábra: A teljesítménystratégiák és a hangulati állapotok összehasonlítása edzésen és versenyen két brit egyetemi kosárlabdacsapat játékosainál [Forrás: saját szerkesztés]

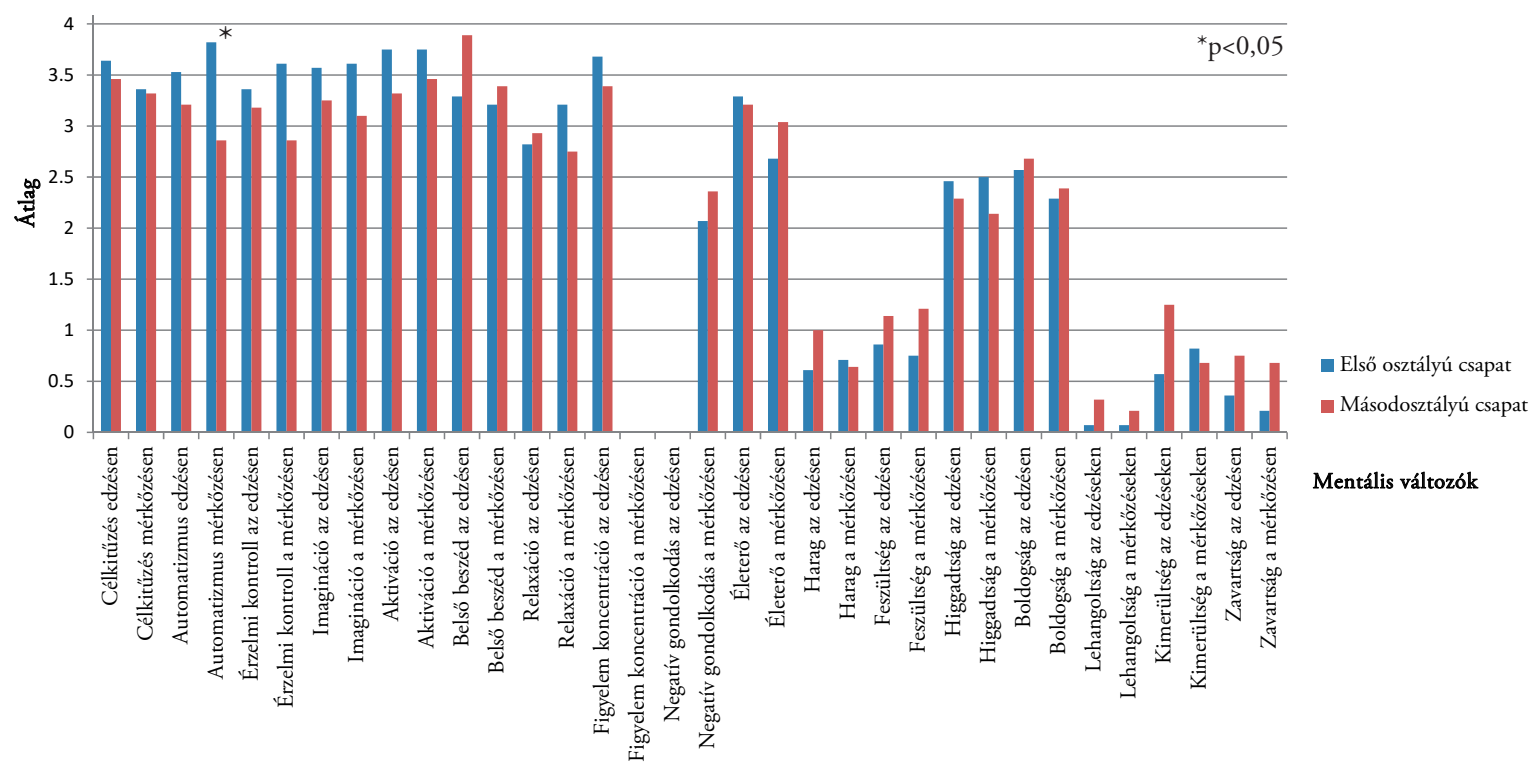

2. ábra: A játékosok teljesítménystratégiájának és hangulati állapotainak összehasonlítása [Forrás: saját szerkesztés] 


\section{Irodalom}

1. Bandura, A. (1986): Social Foundations of Thought and Action. Prentice-Hall, Englewood Cliffs, New Jersey.

2. Boldizsar, D., Soos, I., Whyte, I. és Hamar, P. (2016): An Investigation into the Relationship between Pre-Competition Mood States, Age, Gender and a National Ranking in Artistic Gymnastics. Journal of Human Kinetics, 51: 235-243. http://dx.doi. org/10.1515/hukin-2015-0188

3. Bull, S.J. (1993): Sport Psychology. A SelfHelp Guide. The Crowood Press, Ramsbury, Marlborough Wilshire.

4. Dachen, J. (2012): Test of Performance Strategies among College going Athletes: Differences across Type of Sports and Gender. International Journal of Behavioural, Social and Movement Sciences, 1(4): 139-147.

5. Gyömbér Noémi és Kovács Krisztina (2012): Fejben döl el. Sportpszichológia mindenkinek. Noran Libro, Budapest.

6. Kalmár Zsuzsa (2014): Az utánpótlás és felnött válogatott tornásznők tornaspecifikus attitüdjei és személyiség jellemzöi hazai, illetve nemzetközi összehasonlitásban. PhD értekezés. Testnevelési Egyetem, Budapest.

7. Katsikas, C., Argeitaki, P. és Smirniotou, A. (2009): Performance strategies of Greek track and field athletes: gender and level differences. Biology of Exercise, 5(1): 29-38. http:// dx.doi.org/10.4127/jbe.2009.0023
8. Salovey, P. és Birnbaum, D. (1989): Influence of Mood on Health-Relevant Cognitions, Journal of Personality and Social Psychology, 57: 539-551.

9. Tavakol, M. és Dennick, R. (2011): Making sense of Cronbach's alpha. International Journal of Medical Education, 2: 53-55. http:// dx.doi.org/10.5116/ijme.4dfb.8dfd

10. Taylor, M.K., Gould, D. és Rolo, C. (2008): Performance Strategies of US Olympians in Practice and Competition. High Ability Studies, 19(1): 19-36. http://dx.doi. org/10.1080/13598130801980281

11. Thomas, R.R., Murphy, S.M. és Hardy, L. (1999): Test of performance strategies: Development and preliminary validation of comprehensive measure of athlete's psychological skills. Journal of Sport Sciences, 17: 697-711. http://dx.doi. org/10.1080/026404199365560

12. Williams, M., Hardy, L. és Mutrie, N. (2008): 25 Years of Psychology in the Journal of Sports Sciences. Journal of Sports Sciences, 26(4): 401-412. http://dx.doi. org/10.1080/02640410701765631 